Available online on 15.11.2016 at http://jddtonline.info
Journal of Drug Delivery and Therapeutics
$\begin{gathered}\text { O 2016, publisher and licensee JDDT, This is an Open Access article which permits unrestricted } \\ \text { noncommercial use, provided the original work is properly cited }\end{gathered}$

Research Article

\title{
A COMPARATIVE STUDY OF MORPHOLOGICAL AND ANATOMICAL STRUCTURES OF FOUR OCIMUM SPECIES IN UTTARAKHAND, INDIA
}

\author{
Rawat Rajni*, Tiwari Vandana and Negi K S \\ ICAR-NBPGR, R/S- Bhowali, Niglat, Nainital, Uttarakhand, India \\ *Corresponding Author's Email: riya30rawat@gmai.com
}

\section{ABSTRACT}

In traditional systems of medicine along with holistic approach, different parts of basil (Ocimum spp.) have been prescribed for the treatment of various ailments. Morphological and anatomical characters play a vital role in plant based crude drug identification and standardization. This study aimed to characterize the morphological and anatomical structure of four different species of Ocimum such as Ocimum basilicum var thyrsiflora L. commonly named as Thai basil; Ocimum tenuiflorum L. as Holy or sacred basil; Ocimum gratissimum L. as Shrubby basil or Clove basil and Ocimum viride Willd. as Temple basil or Fever plant of Sierra Leone. This study is useful to correct identification judging the authencity of the plant and to differentiate these species from each other's while undertaking pharmacognostical characterization and evaluation.

Key words: Basil, Anatomical, Morphological, Medicinal crude drugs.

Article Info

Received 01 Aug 2016; Review Completed 05 Sep 2016; Accepted 27 Sep 2016, Available online 15 Nov 2016

Cite this article as:

Rawat R, Tiwari V, Negi KS, A comparative study of morphological and anatomical structures of four Ocimum species in Uttarakhand, India, Journal of Drug Delivery \& Therapeutics. 2016; 6(6):1-6

DOI: http://dx.doi.org/10.22270/jddt.v6i6.1322 URI: http://jddtonline.info/index.php/jddt/article/view/1322

\section{INTRODUCTION}

Medicinal plants are of great importance to human health. That is why the world Health Organization estimates that $80 \%$ of the populations in developing countries rely on traditional medicine for their primary health care (Nathiya et al., 2012)1. Therefore, medicinal plants have played an important role in the socio-cultural and therapeutic need of people. Some of these plants are used as spices and food. Medicinal plants being as a key natural resource and potentially secure drugs are contributing a significant role in mollifying human health by contributing nil side effects herbal medicines. The high cost of allopathic medicine and their potential side effects, encouraged the people to use the traditional medicine.

The Ocimum (Basil) comprises some of the most popular herbs known for aromatic, cuisine, medicinal, ornamental, sacred and several other aesthetic properties in the world. It belongs to the family Lamiaceae, sub family ocimoideae and includes more than 65 different species and varieties distributed in the tropical regions of Asia, Africa, Central and South Africa considered as one of the largest genera of the Lamiaceae family. The name Tulsi is derived from 'Sanskrit' which means "matchless one" (Ghosh 19952 and Simpson and Conner 1986)3. In traditional systems of medicine, different parts (leaves, stems, flowers, roots, seeds and even whole plant) of Ocimum have been recommended for the treatment of various ailments i.e., bronchitis, bronchial asthma, malaria, diarrhea, dysentery, skin diseases, arthritis, chronic fever and insect bite. The essential oil of Ocimum spp. were rich in camphor, citral, eugenol, geraniol, linalool, linalyl acetate and methyl chavicol etc., and being harnessed for successful utilization in industry. There is a variation in the production of these products among different species of Ocimum. Therefore, precise characterization such as anatomical and morphological features of promising species of Ocimum is felt necessary. 
Standardization of herbal drugs is pre-requisite as per global market of herbal medicine. Morphological and anatomical characters play a vital role in crude drug standardization (Agarwal et al., 2013)4. Anatomical characterization is important taxonomic parameters for the certification and quality control of medicinal plants for comparison and correct identification. An investigation of anatomical structures of the species organs is necessary (Sinnott, 1960)5. The present study therefore provides an anatomical characterization of the stems of four species of Ocimum of industrial importance.

The morpho-anatomical structure may be directly affected by variations in the environmental conditions to which plants are exposed during development. The morphological variations help in understanding the genotypic difference in the species and population studied. In addition, such studies on morphophysiological, anatomical and genetic aspects of commercial and industrial crop and endangered species are essential to develop successful standardization or quality parameter and conservation strategies respectively (Ojha, 2014)6. The morphological and anatomical account of a medicinal plant is the first step towards establishing the correct identity and the degree of purity of such materials.

\section{MATERIAL AND METHODS:}

The plant selected for the present study such as Ocimum basilicum var. thyrsiflora (L.) Benth. (EC 387839), Ocimum tenuiflorum L. (NRO 42.), Ocimum gratissimum L. (SKV/RRA/AK/1850) and Ocimum virdi Willd. (NRT 04) belongs to the family Lamiaceae. The field experiment was conducted in the experimental farm field of ICAR-NBPGR, Regional Station-Bhowali, Niglat, Distt- Nainital $\left(29^{0} 20^{\prime} \mathrm{N}\right.$ latitudes, $79^{0} 30^{\prime} \mathrm{E}$ longitudes) at an altitude of $1450 \mathrm{~m}$ in two consecutive year 2014-15, using ABD(Augmented Blocks Design) method in three rows (8 Plants in each row). The type of soil was grey-brown. Seeds were sown in the greenhouse in the first week of March and the seedlings were planted in the field beds of size $2.0 \times 1.2 \mathrm{~m}$; distance plant to plant $25 \mathrm{~cm}$ and row to row distance $60 \mathrm{~cm}$ in the last week of April. Plants at flowering stage were used for morphological characterization by randomly selected 5 plants of each accessions or variety. Minimum and maximum temperature from March to Sept $5.37^{\circ} \mathrm{C}$ to $18.20^{\circ} \mathrm{C}$ and $17.87^{\circ} \mathrm{C}$ to $29.37^{\circ} \mathrm{C}$ with average rainfall $228 \mathrm{~mm}$ in 2014 and $5.20^{\circ} \mathrm{C}$ to $18.32^{\circ} \mathrm{C}$ and $16.83^{\circ} \mathrm{C}$ to $28.58^{\circ} \mathrm{C}$ with $229 \mathrm{~mm}$ of rainfall in 2015 . Irrigation was provided on daily basis up to 15 days after transplanting and establishment of plant population. From time to time irrigation and in cultural practices were coined out. The quantitative and qualitative characters were measured before harvesting. In order to document the morphological, agro- botanical and economic traits, the standard descriptors was used (Singh et al., 2013)7.

For morphological characterization colour of aerial parts, odour, taste, size and shape of lamina, lamina margin, plant height, stem colour, flower colour, seed shape, seed colour, 1000-seed weight and plant canopy were recorded. For anatomical investigation the fresh or preserved (in FAA) materials were taken for microscopic studies. Middle part of plants stem was taken for the anatomical studies. Section taken by moving the blade back and forth and placed in watch glass containing water. Thin section were selected and placed in chloral hydrates and cleared by boiling. Cleaned sections were stained by using Phloro-glucinol and concentrated hydrochloric acid. One thin section was taken out and mounted on a clean glass slide. A drop of glycerin was added and covered with the cover slip. This slide was observed under microscope and photomicrographs of with different magnifications were taken with Olympus CX 31 Lica ATC 2000 (digit 3) microscopic unit.

\section{RESULTS}

Morphology:

The four species of Ocimum were shown a great variation of phenotypic characters like lamina length of O. gratissimum $(12.4 \mathrm{~cm})$, O. tenuiflorum $(4.3 \mathrm{~cm}), O . b$. var thyrsiflora $(5.7 \mathrm{~cm})$ and $O$. viride $(5.6 \mathrm{~cm})$. Lamina shape is sub-ovate in O.b. var thyrsiflora, O. tenuiflorum; ovate in $O$. gratissimum and $O$. viride. Lamina margin is sub-serrate in $O . b$. var thyrsiflora and $O$. tenuiflorum while serrate in $O$. gratissimum and $O$. viride. The plant height varies from $51.46 \mathrm{~cm}$ to $102.6 \mathrm{~cm}$ (Fig:-1). The smallest plant population of $O$. tenuiflorum and the tallest plants of $O$. gratssimum were observed. The plant canopy was ranged from $692.24 \mathrm{~cm}^{2}$ of $O$. tenuiflorum to $3843.94 \mathrm{~cm}^{2}$ of $O$. viride (Fig:-1.1). Stem colour is light green in $O . b$. var. thyrsiflora, purple green in $O$. tenuiflorum, dark brown in $O$. gratissimum and dark green in $O$. viride. Flower colour sowed a great variations among these four species of Ocimum i.e., O.b. var. thyrsiflora (white), O. tenuiflorum (purple white), $O$. gratissimum (creamy white) and $O$. viride (pink purple). Seed shape of O.b. var thyrsiflora was ellipsoid and globose in rest three species of Ocimum was recorded. Seed colour is black in O.b. var. thyrsiflora and $O$. viride and brown in $O$. gratissimum and O. tenuiflorum. 1000seed weight ranges from 0.30 to $0.90 \mathrm{~g}$, bold and high weight seed found in O. gratissimum $(0.90 \mathrm{~g}), O . b$. var. thyrsiflora $(0.80 \mathrm{~g}), O$. viride $(0.50 \mathrm{~g})$ and $O$. tenuiflorum $(0.30 \mathrm{~g})$ ( Table 1$)$.

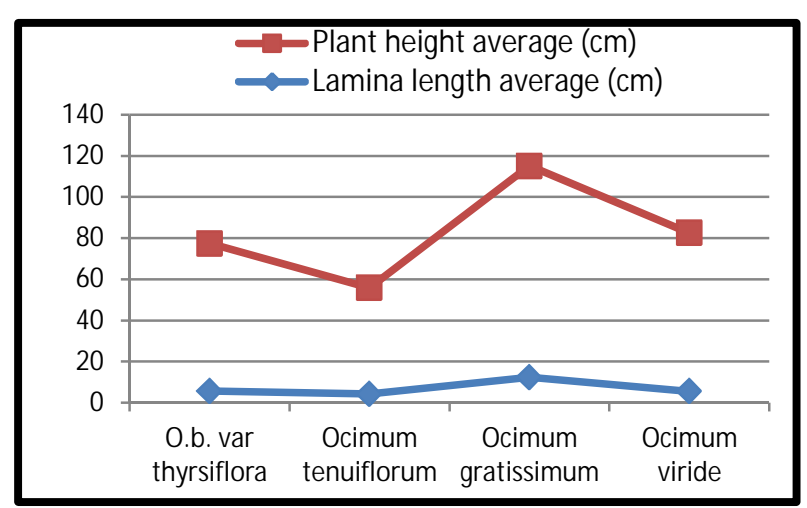

Figure 1: Quantitative characters on the basis of Average value of four species of Ocimum. 


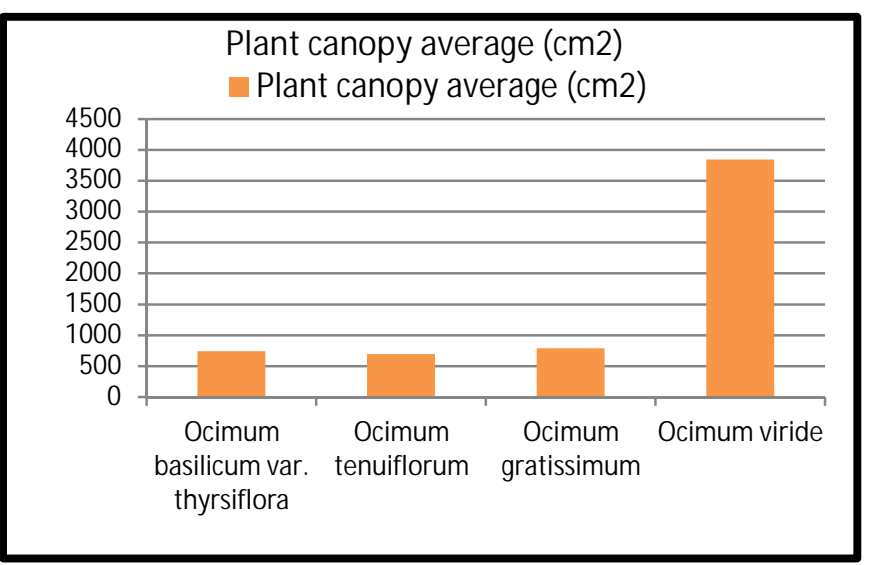

Figure 2: Plant canopy $\left(\mathrm{cm}^{2}\right)$ of four species of Ocimum.

Table 1: Morphological features of the four species of Ocimum

\begin{tabular}{|l|l|l|l|l|}
\hline \multirow{2}{*}{ Parameter } & \multicolumn{4}{|c|}{ Species of Ocimum } \\
\cline { 2 - 5 } & $\begin{array}{l}\text { Ocimum basilicum } \\
\text { var. thyrsiflora (L.) } \\
\text { Benth. (Thai basil) }\end{array}$ & $\begin{array}{l}\text { Ocimum tenuiflorum L. } \\
\text { green type (Holy or } \\
\text { sacred basil) }\end{array}$ & $\begin{array}{l}\text { Ocimum } \\
\text { gratissimum } \\
\text { Clove basil }\end{array}$ & $\begin{array}{l}\text { Ocimum viride } \\
\text { Willd. Fever plant } \\
\text { of Sierre Leone }\end{array}$ \\
\hline Odour & Clove like scent & $\begin{array}{l}\text { Sweet, green herbaceous } \\
\text { top noted and appreciable } \\
\text { note of cloves under tones. }\end{array}$ & $\begin{array}{l}\text { Strongly scented } \\
\text { than other varieties } \\
\text { or species }\end{array}$ & $\begin{array}{l}\text { Highly scented, } \\
\text { district }\end{array}$ \\
\hline Taste & No pungent, Soft & Light pungent, light bitter & $\begin{array}{l}\text { Clove-mint type, } \\
\text { strong pungent }\end{array}$ & $\begin{array}{l}\text { Sweet, light } \\
\text { pungent and betel } \\
\text { like taste }\end{array}$ \\
\hline $\begin{array}{l}\text { Lamina length } \\
\text { (cm) }\end{array}$ & 5.7 & 4.3 & 12.4 & 5.6 \\
\hline shape of lamina & Sub-ovate & Sub-ovate & Ovate-lanceolate & Ovate \\
\hline Lamina margin & Sub serrate & Sub serrate & Serrate & Serrate \\
\hline Plant height (cm) & 71.68 & 51.46 & 102.6 & 76.9 \\
\hline Stem colour & Light green & Purple green & Dark brown & Dark green \\
\hline Flower colour & White & Purple white & Cream colour & Pink purple \\
\hline Seed shape & Ellipsoid & Globose & Globose & Globose \\
\hline Seed colour & Black & Brown & Brown & Black \\
\hline $\begin{array}{l}\text { 1000-Seed weight } \\
\text { average }\end{array}$ & 0.80 & 0.30 & 0.90 & 0.50 \\
\hline $\begin{array}{l}\text { Plant canopy } \\
\left.\text { average (cm }{ }^{2}\right)\end{array}$ & 741.20 & 692.24 & 787.53 & 3843.94 \\
\hline
\end{tabular}

Anatomy: I. Ocimum basilicum var thyrsiflora L.: The stem has a primary structure only in the upper third part, and a secondary structure in the other two. The epidermis layer is uniseriate, and has been covered by a thin cuticle layer. The parenchymatous cortex is collenchymatic in a hypodermal position. The large bundles have radial ranges of ligneous vessels separated by uni- or multi-seriate areas of parenchymatous cells.
The sclerenchyma and fibers, at the end of the large phloem vascular bundles, have less thickened but still cellulosic walls, which will be thicker and lignified from the base to the top of the stem. The number of glandular and tectorial trichomes per surface unit is decreased from the base to the top of the stem. The tectorial trichomes are uniseriate, consisting of three cells, with an acute apex and a bi-or multicellular basis \{Fig 4 (a)\}. 


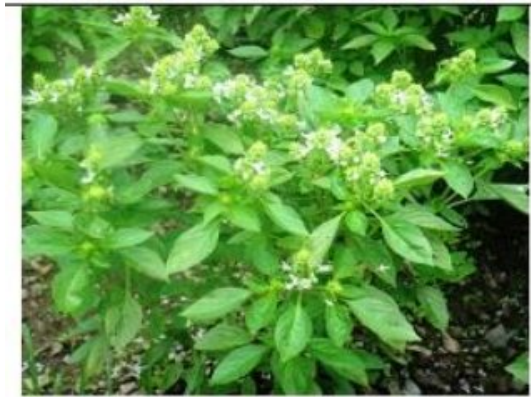

Ocimum basilicum var thyrsifiord

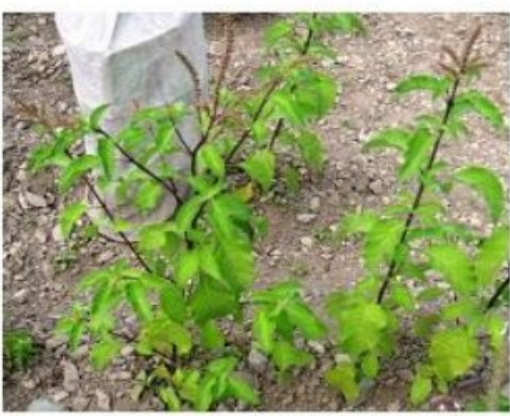

Ocimon gratiss bmum

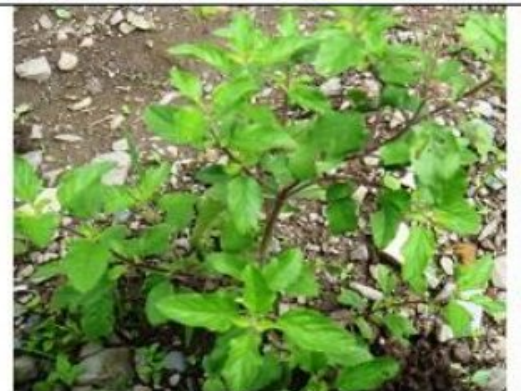

Ocimum sanctum

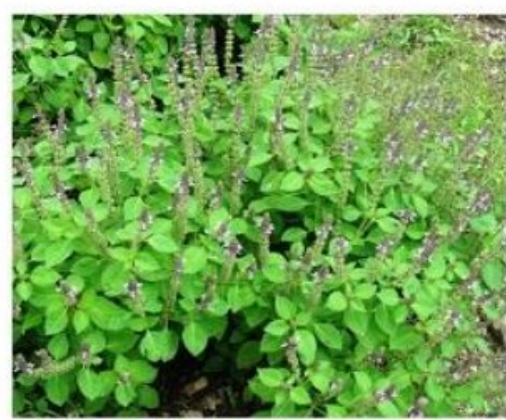

Ocónum virdi

Figure 3: Plant population of Four species of Ocimum

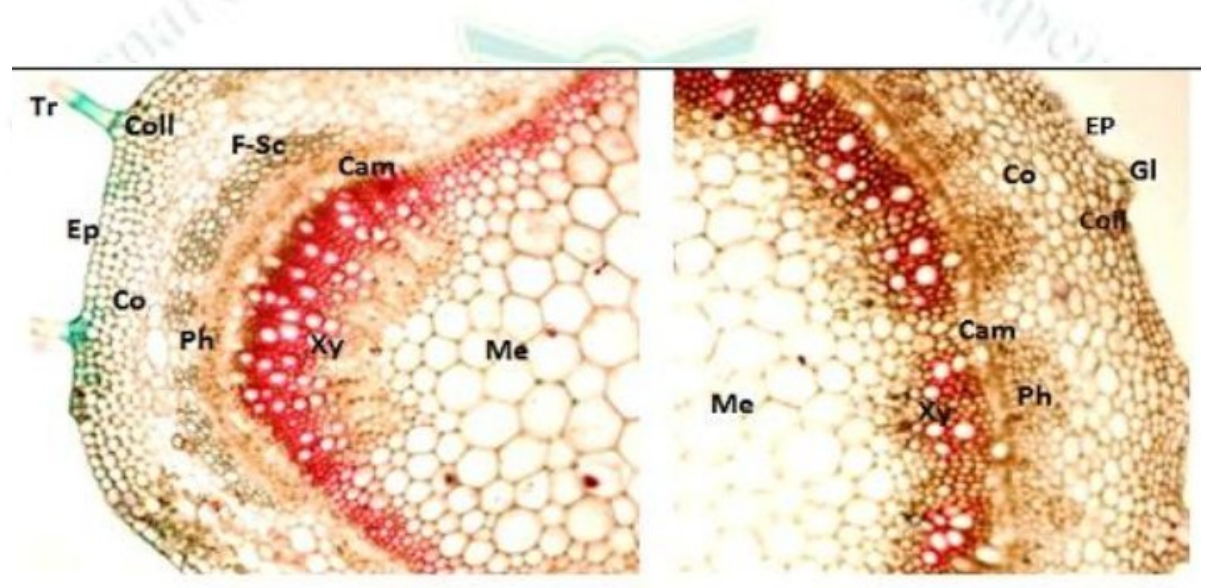

(a) Ocimon basilicuon var thyrsifiora

(b) Ocimon sanctum

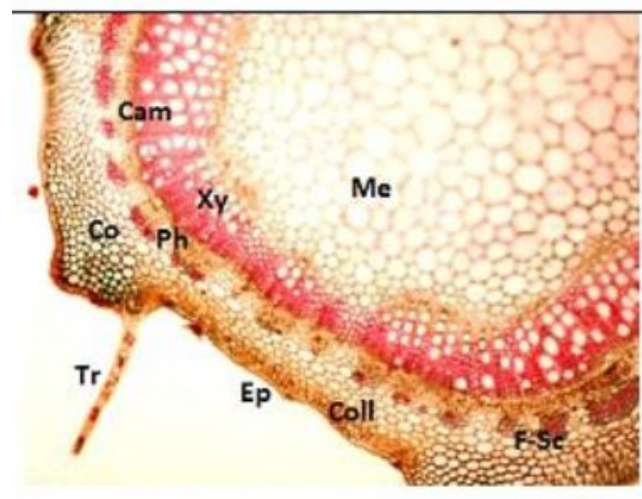

(c) Ocbmum gratissimon

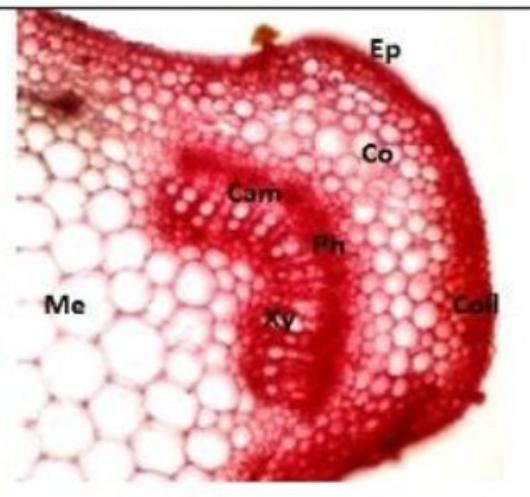

(d) Ocimum wir di

Figure 4: Stem anatomy of Four species of Ocimum

Abbreviations: Ep: Epidermis, Coll: Collenchyma, Co: Cortex, F-Sc: Fiber-Sclerenchyma, Ph: Phloem, Xy: Xylem, Me: Medulla, Gl: Glandular trichome, Tr: Tectorial Trichome. 
II. Ocimum tenuiflorum L.: The young stem is quadrangular in outline. Outermost layer is epidermis (EP) composed of tangentially elongated isodiametric cells and covered by their cuticle. Hypodermis is slightly collenchymatous (Coll). Cortex (Co) is parenchymatous with air spaces. Stele has four vascular bundles between them. Vascular bundles are collateral and open. Xylem (Xy) is without fiber tracheid with libriform fibers. Pith (M) in centre consists of lignified parenchymatous cells. sclerenchyma and fibers, at the end of the large phloem vascular bundles are present. Scleranchymatous tissue surrounds the phloem group of vascular bundles, as can be seen. Secondary thickening develops from cambial activity producing thin phloem ring towards the exterior and thicker xylem ring on the interior. Xylem is without fiber tracheid with libriform fibers $\{$ Fig 4 (b) $\}$.

III. Ocimum gratissimum L.: The cross section of hexagonal stem \{Fig 4 (c) \} has two parts; the bark and the central cylinder. The bark is thin, has three primary tissues (epidermis, cortical parenchyma and collenchyma). The epidermis is consists of a single base of small contiguous rectangular cells, the wall is thin and cellulose. The cortical parenchyma consists of several layers of polygonal cells with thin walls. The central cylinder is more developed than the bark. A fundamental parenchyma is observed in which differs from primary tissues (wood, phloem parenchyma) and two secondary tissues (wood and secondary phloem). The primary wood is centrifuged and the secondary phloem and secondary wood are arranged in radial alignment. sclerenchyma and fibers, at the end of the large phloem vascular bundles are present. Scleranchymatous tissue surrounds the phloem group of vascular bundles, as can be seen. The narrow parenchyma includes meatus and is formed of large polygonal cells cellulose walls $\{$ Fig 4 (c) \}.

IV. O. virdi Willd. : The young stem is quadrangular in outline. Outermost layer is epidermis (EP) composed of tangentially elongated isodiametric cells and covered by their cuticle. Hypodermis is slightly collenchymatous (Coll). Cortex $(\mathrm{Co})$ is parenchymatous with air spaces. Stele has four vascular bundles between them. Vascular bundles are collateral and open. Xylem (Xy) is without fibre tracheid with libriform fibres. Pith $(\mathrm{M})$ in centre consists of lignified parenchymatous cells. Pith in the centre consists of lignified parenchymatous cells $\{$ Fig 4 (d) $\}$.

\section{REFERENCES:}

1. Nathiya S, Santhi N and Kalaiselvi S, A comparative study on ontogenic expression of antioxidants and secondary metabolites in Withania somnifera: Int. Res. J. Pharm., 2012, 3(1), 2010-1015.

2. Ghosh GR Tulsi (N.O. Labiatate, Genus- Ocimum), New Approaches to Medicine and Health. NAMAH., 1995, 3, 2329.

3. Simpson BB and Conner OM, Economic Botany Plants in Our World. McGraw Hill Book Company, Hamburg, 1986.

4. Agarwal S, Kumar VR and Kumar A, Pharmacognostical Characterization of Ocimum spp.: Journal of Pharmacognosy and Phytochemsistry, 2013, 2(1), 219-224.

\section{DISCUSSION:}

These four species of Ocimum showed a great variability in morphology but anatomically the variations is not very fine. Earlier studies confirmed great morphological variability available in Ocimum basilicum (Nurzynska-Wierdak, 20138; Negi et al, 20159; Rawat et al., 2016) ${ }^{10}$. Morphological study of $O$. gratissimum was done by Chirstian $2012^{11}$, Prabhu et al., $2009^{12}$. Morphological variability in holy basil was earlier reported by Malav et al., 2015 ${ }^{13}$. The quadrangular transaction is frequently described for Lamiaceae (Metcalf and Chalk, 1988 ${ }^{14}$; Barroso, $1991)^{15}$, as well as the evident collenchymas in the four angles (Cronquist, 1981) ${ }^{16}$, which is considered of diagnostic value according to Metcalf and Chalk $1988^{14}$. Metcalf and Chalk (1972) $)^{17}$ also determined some scleranchymatous tissue surrounds the phloem groups of vascular bundles, as can be seen the same in the two species of basil (Ocimum basilicum var. thyrsiflora and Ocimum gratissimum). The sclerenchyma is the predominant support tissue for species that grown in dry environments as recorded by Faria $(2008)^{18}$. Pharmacognostical characterization of Ocimum tenuiflorum and Ocimum gratissimum is earlier done by (Agarwal et al., 20134; Fofie et al., 2014 ${ }^{19}$ )

\section{CONCLUSION:}

Plant morphology is study of the physical form and external structure of plants. It represents the study of the development, form, and structure of plants and origin (Harold et al., 1987) ${ }^{20}$. The present study will help to maintain proper standards of assigned medicinal plants and may result to check other adulterated mixture of fake crude drugs. This will also assist to maintain their uniqueness of well known ancient system of medicines. Thus in recent years there has been an emphasis in pharmacognostical standardization of medicinal plants of therapeutic potential.

Anatomical characters of diagnostic value in four species of basil were recorded in the present study. This information is important, as it helps in the identification of these species and contributes to its quality control, and evaluation. This investigation helps to differentiate from the closely related other species and varieties of Ocimum.
5. Sinnot EW, Plant Morphogenesis, MCGraw-Hill Co, New York, USA, 1960.

6. Ojha SN, Studies on Ecological, Taxonomic, Ethnobotanical and Chemotypic Variation in 'Oregano' (Origanum vulgare L.) and Prospectus of its Cultivation. Ph.D. dissertation. Kumaun University, Nainital, 2014.

7. Singh BM, Mahajan, RK, Srivastva, U and Pareek, SK, Minimal Descriptor of Agri- Horticultural Crops, Part-IV: Medicinal and Aromatic Plants, ICAR-NBPGR, Pusa, New Delhi, 2013. 
8. Nurzynska-Wierdak, R, Analiza zawartoscii skladu chemicznego olejku dwoch form bazylii wonnej (Ocimum basilicum L.). Ann. UMCS, EEE, IX Suppl., 2001, 189-193.

9. Negi K.S, Ojha SN, Koranga SS, Rayal A and Mehta PS, Sweet basil ke Saundrya Udyog mein badti mang: Kheti, 2015 66(10), 18-22.

10. Rawat Rajni, Negi, KS, Mehta, PS, Tiwari Vandana, Verma SK and Bisht IS, Study of six varieties of sweet basil (Ocimum basilicum L.) and their morphological variations: $J$. Non- Timber For. Prodts, 2016, 23(1), 17-22.

11. Christian OA, Agro-morphological variability of Ocimum gratissimum L. and three other accessions of basil in southwestern Nigeria. The African J. of Plant Sci. and Biotech. 2012, 7(1), 89-92.

12. Prabhu KS, Lobo R, Shirwaikar AA and Shirwaikar A, Ocimum gratissimum: A Review of its Chemical, Pharmacological and Ethnomedicinal Properties: The Open Complementary Medicine Journal, 2009, 1, 1-15.

13. Malav P, Pandey A, Bhatt KC, Krishnan, S and Bisht IS, Morphological variability in holy basil (Ocimum tenuiflorum
L.) from India. Genet Resour Crop Evol., 2015, 62, 12451256

14. Metcalfe CR and Chalk L, Anatomy of Dicotyledons. Vol II. Clarendon Press, Oxford, 1988.

15. Barroso GM, Sistematica de angiospermas do Brasil. Vicaso, Universidade Federal de Vicaso, 1991.

16. Cronquist A, An Integrated System of Classification of Flowering Plant. Columbia University Press, New York, USA; 1981.

17. Metcalfe CR and Chalk L, Anatomy of Dicotyledons. Vol I. Clarendon Press, Oxford; 1972.

18. Faria MT,.Morfologia,anatomia, histoquimica de especies Dogenero hypenia Mart. ex Benth. In: Lamiaceae Ocorrentes no Cerrodo do Goias. Dissertacao de Mestrado [Harley R (ed.)], programa de pos-graduacao em Botanica, Universidade Federal de Goias; 2008.

19. Fofie NBY, Coulibaly K and Kone BD, Phamacognostic study of Ocimum gratissimum Linn.: Pharmafooe plant. J.Pharmacognosy and Phytochemistry, 2014, 2(5), 74-79.

20. Harold CB, Alexopoulos CJ and Delevoryas T. Morphology of Plants and Fungi. $5^{\text {th }}$ ed. Harper-Collins, New York; 1987. 